\title{
The Increasing Role of English in Thai Academic Publications
}

\author{
Kittinata Rhekhalilit (กิตตินาถ เรขาลิลิต) \\ Kasetsart University, Bangkok, Thailand \\ kittinata@gmail.com \\ Siriporn Lerdpaisalwong (ศิริพร เลิศไพศาลวงศ์) \\ Kasetsart University, Bangkok, Thailand \\ Joybrake77@hotmail.com
}

\begin{abstract}
The role of English as a medium of communication especially in the academic domain has been accelerated. This is reflected in the growing number of English language academic journals in non-English dominant countries such as: China, India and Spain (Ren and Rousseau 2004; Xian 2006). Similar to other peripheral countries, Thailand is no exception. This situation results in competition between the national language and English. This present study compares the language choice of academic papers published in Thai national journals in two major fields: science, and its counterpart, humanities and social science. The data collection includes a corpus of 663 articles published in 2005 and in 2015, specifically 346 from Science and 317 from Humanities and Social science. We have hypothesized that English plays a more significant role in scientific journals compared to those in Humanities and Social science. In addition to the language choice in Thai academic journals, a questionnaire was also distributed to 73 respondents to investigate the language ideology of Thai scholars in choosing a language for their manuscripts. The result reveals that many Thai scholars choose English in writing manuscripts due to the lack of technical terms in their field in Thai whereas some of them prefer Thai due to the publication process and the Thai readership orientation.
\end{abstract}

\section{Keywords}

English as an academic lingua franca - Thai academic publications - Thai scholars language choice

(C) RHEKHALILIT AND LERDPAISALWONG, 2019 | DOI:10.1163/26659077-02203004

This is an open access article distributed under the terms of the prevailing CC-BY-NC License at the time of publication. 
บทคัดย่อ
บทบาทของภาษาอังกฤษที่เพิ่มขึ้นในการเผยแพร่วารสารวิชาการในประเทศไทย

ในปัจจุบัน บทบาทของภาษาอังกฤษในแวดวงวิชาการมีความสำคัญมากขึ้นอย่างรวดเร็วโดย สะท้อนให้เห็นได้จากจำนวนที่เพิ่มขึ้นของวารสารวิชาการภาษาอังกฤษในประเทศที่ไม่ใช้ภาษา อังกฤษเป็นภาษาประจำชาติ เช่น จีน อินเดีย และสเปน (Ren and Rousseau 2004; Xian 2006) รวมถึงประเทศไทย สถานการณ์นี้ส่งผลให้เกิดการแข่งขันระหว่างภาษาประจำชาตินั้น ๆ กับภาษา อังกฤษ การศึกษาชิ้นนี้มีวัตถุประสงค์เพื่อเปรียบเทียบการเลือกภาษาของบทความทางวิชาการที่ตี พิมพ์ในวารสารวิชาการของไทยในสองสาขาหลัก ได้แก่ สาขาวิทยาศาสตร์และสาขามนุษยศาสตร์ และสังคมศาสตร์ ข้อมูลที่ใช้ในการวิจัยประกอบด้วยบทความทางวิชาการจำนวน 663 บทความที่ตี พิมพ์ในปี 2548 และปี 2558 โดยแบ่งออกเป็นบทความทางสาขาวิทยาศาสตร์ 346 บทความและสาขา มนุษยศาสตร์และสังคมศาสตร์ 317 บทความผู้วิจัยมีสมมติฐานว่า ภาษาอังกฤษมีบทบาทสำคัญ มากกว่าในวารสารทางวิทยาศาสตร์เมื่อเทียบกับวารสารในสาขามนุษยศาสตร์และสังคมศาสตร์ นอกจากนี้ ผู้วิจัยยังได้รวบรวมข้อมูลโดยการใช้แบบสอบถามเพื่อวัดทัศนคติทางภาษาของนัก วิชาการ ไทยจำนวน 73 คนเกี่ยวกับการเลือกภาษาเพื่อเขียนบทความทางวิชาการ ผลที่ได้แสดงให้ เห็นว่าเหตุผลหลักที่นักวิชาการไทยมักเลือกใช้ภาษาอังกฤษในการเขียนบทความได้แก่การขาดคำ ศัพท์เฉพาะทางในสาขาวิชาของตน ในขณะที่บางส่วนที่เลือกใช้ภาษาไทยในการเขียนบทความมี เหตุผลหลักได้แก่ กระบวนการทางการตีพิมพ์ และต้องการเน้นกลุ่มผู้อ่านคนไทย

In the era of globalization, English has played a significant role as a global language in different communicative aspects, especially in international academic exchange among scientists, scholars, and researchers, as Crystal (2003: 110) stated "English is the medium of a great deal of the world's knowledge, especially in such areas as science and technology." English has been universally referred to as the global academic language (Graddol 2006), English as an international language of science or EILS (Tardy 2004), as well as the world's lingua franca of science (Sano 2002). In this current paper English is considered as an academic lingua franca or EALF (Lillis et al. 2010), since the use of English in academic domain is not limited to science and technology, but is also found in humanities, and other non-science disciplines.

Throughout history, language policies of academic journals have shifted from plurilingualism including languages such as German, French, Russian and other languages to a monolingual policy preferring English. According to reports by Xian (2006: 9) and Canagarajah (2002), a massive 80 percent of publications in Scopus-indexed journals are written in English. The greatly increasing number of English-language scientific journals in non-English dominant countries such as in China (Xian 2006: 9) also implies the prevailing role of English in academia not only in English L1 countries but also in those with 
a non-native background. Likewise, Hamel (2007) studied the role of English in international scientific periodical literature in different disciplines for a century (1880-1980) and found that despite the decline in other European languages including: French, German, Russian, and Italian, the use of English continuingly increased throughout the century. In some cases, the language policy of academic journals includes varieties of English, outside the mainstream of American and British English. Henshall (2018) reports the change in language policy of the Social Sciences Citation Index or SSCI indexed economics journals published in many English-speaking countries. Her study suggests the change in acceptance of more diverse varieties of English by academic journals as found in her 2012 study (Henshall 2012). This study shows how the role of different English varieties has expanded in the academic domain.

Obviously, the use of English is increasing across different genres. In formal academic publications and in online scientific communications such as posts on Twitter. Yu et al. (2018) investigates language distribution among scientific tweets posted by scientists from different non-English dominant countries ranging from European countries such as Germany, France, and Spain to Asian countries including South Korea, Japan, and Saudi Arabia. The finding confirms the universal trend toward an overwhelming majority of English scientific tweets (over 90\%) in many countries whereas other languages are a tiny proportion. Thailand is no exception to this trend. In informal online scientific tweets posted by Thai users, English makes up the highest proportion, approximately $95 \%$, while Thai makes up only $2.9 \%$ of the whole collected tweets (Yu et al. 2018: 612). This comparative study of language distribution highlights the expansion of English from formal publications to casual scientific communications among non-native English users, including non-English dominant countries like Thailand.

However, the extreme dominance of English in academic situations has provoked some concerns related to the competition between English and national languages in many countries, especially those with a non-English dominated background. According to Hamel (2007), after World War II, when English gained its status over other languages (i.e., French, Spanish, Russian, Chinese, Japanese, Arabic, Hindi, German and Portuguese), English has extended its international domain more and more. This has created concern of English diminishing the role of other languages. For example, the role of languages such as French, Spanish, Russian, Chinese, Japanese, Arabic, Hindi, German and Portuguese, may shift into a role with little international diffusion. In addition, the fact that the USA has become a dominant country as an economic and political world power since the end of the $19^{\text {th }}$ century has provided opportunity for English to become a dominant language in international communication including the field of science. As a result, science academic periodicals using 
other languages (i.e., French, Spanish, Russian, Chinese, Japanese, Arabic, Hindi, German and Portuguese) have lost their attraction as places for publications by authors. Some useful and important original information in natural sciences and medicine which are not published in English may not receive much attention either. Hamel (2007: 56 and 61) supported these statements by showing the development of language shift between 1880 and 1980 from German, French, Russian, and Japanese to English and providing a comparison between the publication growth in German and English in Biological Abstracts (i.e., 1980-1995) and MathSciDisc (i.e., 1975-1995). Apart from science, Gotti (2017) also stated that the spread of English in global communication has been considered a threat to important existing differences among non-English speaking communities. Besides, English-medium policies could minimize the role of national languages for academic purposes. In other words, the trends of English as a dominant language could also provide negative consequences (e.g., bias against other languages and non-native speakers) in academic domains. For example, there could be a restriction of academic gatekeepers in the world, which leads to linguistic monopoly, scholarly chauvinism, cultural imperialism, and unintentional discrimination against non-native speakers on the part of the editors of specialized publications (Curry and Lillis 2004, as cited in Gotti 2017; Canagarajah 2002, as cited in Gotti 2017; Van Dijk 1994: p. 276 as cited in Gotti 2017).

Nevertheless, Crystal (1997 as cited in Hamel 2007) contended that under the label of globalization and the ideology of English as an international language, it is quite difficult to claim that English belongs to any country or under the control of any group of native speakers. Moreover, in academic discourse domains, Gotti (2017) has pointed out that although the homogenizing trends of English in the world community have increased, for academic discourse there is no uniformity because of factors such as language competence, disciplinary field, community membership, professional expertise, and generic convention as well as local tradition and culture.

As described above, previous studies have confirmed the increasing role of English as an academic lingua franca in different non- English dominant countries. However, only few researchers have addressed the issue of the role of English in Thai national academic journals. As a result, this paper compares the number of English and Thai articles published in Thai national journals in 2005 and in 2015 for determining the language choice of academic publications in different disciplines, as well as for the justification of Thai scholars' language choice for their academic papers.

This paper is divided into five sections. The first section, as described earlier, gives a brief overview of the role of English in academia. The second section 
specifically explains the role of English in academia of Thailand either as a medium of instruction or a language of written academic publications. Then, the details of this current study including the methodology is presented in the third section. In addition, the results of the data analysis are fully explained in the fourth section for the quantitative analysis and the fifth section for the justification of Thai scholars' language choice. Lastly, the discussion and conclusion can be found in the final section.

\section{$2 \quad$ The Role of English in the Academic Domain of Thailand}

Even though Standard Thai plays a very significant role as the only national and official language of Thailand, English has become significant among Thai scholars in many different aspects. As the most widely used foreign language, English has been taught in Thai schools as an obligatory subject. English has existed in classrooms in Thailand since 1921 (Wongsothorn 2000 as cited in Glass 2009; Foley 2005 as cited in Glass 2009). The importance of the English language has gradually grown until 1996 when the English language was included in the national curriculum for both primary and secondary education. In 2006, English became the primary basis for admission to Thai public universities. The English writing proficiency of Thai students has been found to be quite low (Foley 2005 as cited in Glass 2009). One of the reasons is that Thai English teachers have not received enough training. For example, physical education teachers who have limited skills in English could be asked to teach English classes (Kirtikara 2005 as cited in Glass 2009). Biyaem (1997 as cited in Wiriyachitra 2002) presented many factors that have affected English language teaching and learning. For teachers, those factors were too high of a teaching load, large classroom sizes, and lack of English language skills and knowledge of native-language cultures. On the students' part, the factors that hindered them from becoming proficient were that it interfered with their first language (i.e., Thai), lack of opportunities to use English in everyday life, unchallenging English lessons, and lack of responsibility of their own learning. Wiriyachitra (2002) stated that these factors prevent Thai leaners from catching up with a fast-changing society. Therefore, there was the establishment of the National Education Act derived from Thailand's new constitution adopted in 1997 which played an important role in Thai educational reform. Under such reform, she contended that life-long learning was promoted together with an independent and learner-centered approach. Teacher education was also the focus. With the emergence of English as a world language and new technologies, the National Education Act of 1997 led to the following changes in Thai 
English language teaching and learning scenarios, as explained in Wiriyachitra (2002: 2-5) as follows. First, there have been more and more international programs at a tertiary level. Second, there have been some changes in school level. English has become a compulsory foreign language subject in school since grade one. Teachers have been expected to improve their English skills, every two years. Third, there were also changes with language teaching and learning in the tertiary level. Those changes include the fact that learners have to take an English proficiency test constructed by the Ministry of University Affairs. Then the scores from the test would be used to place those students into an English course which suits their level of proficiency. For non-Englishmajor students who choose English as their language subject, they must take at least 4 compulsory English courses. Every student needs to take an English proficiency test before leaving university. The results from the test could be used for their further study in Thailand. Fourth, self-assessment learning centers and IT have been established in many schools and universities. Last but not least, the language proficiency of students must be evaluated through the quality assurance system.

Glass (2009) examined the English writing habits of Thai undergraduates at a Thai public university showing that Thai learners were in contact with speakers of English from Inner, Outer, and Expanding Circle countries. However, they wrote in English to other Thai's more than to people of other countries. The reasons they wrote to other Thai's in English varied. For instance, the software in their computers did not support the use of Thai. Some of them stated that they could not type in Thai. Some mentioned that their target audiences were both Thai's and non-native Thai's. Other participants said that they could express themselves better in Thai, while others simply wanted to write in English.

Apart from its function as a medium of instruction in Thai academia, English has been chosen as a medium of academic publications among Thai scholars for quite a long time. At present, according to the 2018 database recorded by Thai-Journal Index Citation Center (TCI), there are approximately 855 academic journals actively published in Thailand. To be specific, among 347 journals from science and technology, there are 8o journals titled in English and offer English only language policy. Similarly, only 71 English language journals can be found out of 508 journals in the Arts and Humanities. As summarized in Table 1, in both fields, Thai titled journals with a Thai-English bilingual policy $(82 \%)$ substantially outnumber those with a monolingual English policy $(18 \%)$. It might be implied that even though English is significantly important in international journals, it is relatively less popular among Thai academic communities. 
TABLE 1 The number of actively published Thai academic journals

\begin{tabular}{llllll}
\hline & $\begin{array}{l}\text { Thai titled } \\
\text { journals }\end{array}$ & \multicolumn{3}{l}{$\begin{array}{l}\text { English titled } \\
\text { journals }\end{array}$} & Total \\
& & & & \\
\hline Science and Technology & 267 & $77 \%$ & 80 & $23 \%$ & 347 \\
Arts and Humanities & 437 & $86 \%$ & 71 & $14 \%$ & 508 \\
Total & 704 & $82 \%$ & 151 & $18 \%$ & 855 \\
\hline
\end{tabular}

In Thailand, Thai academic journals are required to meet the standard of ThaiJournal Index Citation Center. According to http://www.kmutt.ac.th/jif/public_html/quality_TCI57.html (n.d.), both science and non-science journals are ranked into groups, based on their qualifications as described as follows. The criteria are divided into major and minor criteria. The major and obligatory criteria emphasize their punctuality, peer-review requirements, and at least 3 years of publications. In addition, the minor criteria include other aspects such as format consistency, editorial teams from both inside and outside the institution, and an updated website. On these bases, journals are classified into three levels according to the acquired scores from the TCI committee. The TCI 1 journals are those, which completely pass all the major criteria and pass at least 4 minor criteria. They are prospective journals in the Asian Citation Index (ACI). Those classified into TCI 2 are those that pass the major criteria but do not pass at least 4 minor criteria whereas those in TCI 3 do not pass any of the major criteria.

From our personal observation the number of English-language articles in Thai national academic publications has increased from those previously published especially by scholars in scientific fields as supported by Pupipat (1998) who interviewed a number of Thai scientists from basic science, agricultural science, and interdisciplinary fields. The findings revealed four reasons why most Thai scientists liked to write their first draft in English. First, it saved the authors' time from translating from Thai into English during the drafting process. Second, they were familiar with reading and writing English scientific papers. Third, technical terms were unavoidably in English. And finally, they thought that by writing in English, it could prevent them from plagiarizing the original text. These imply the increasing role of English in Thai academic communities. As a result, in this study, we would like to examine the growth of English in Thai national journals by comparing the number of articles written in either Thai or English in two periods of time, namely 2005 and 2015. In this 
paper, only journals with TCI 1 basis are involved in the data collection. The next chapter will fully describe the methodology of this study.

This study analyzes the language choice in academic articles by disciplinary domain among Thai researchers. This section focuses on the quantitative data showing language choice specifically between English and Thai in composing academic papers by Thai scholars. The following section, drawing on qualitative data from questionnaires, identifies the reasons for language choice in Thai academic publications.

The quantitative data includes a collection of 663 research and review articles from Thai national academic journals. We chose to analyze articles published in TCI1 journals because these journals are nationally accredited publications which include peer-reviewed selection process. In addition, these journals are popular and widely cited among Thai scholars. Furthermore, in order to certify the Thai authorship of the papers, the articles must be written by Thais, and in the case of multiple authors, the first author must be Thai. Most importantly, these journals must offer a bilingual policy in manuscript submission; that is, they must accept manuscripts written either in Thai or in English. The latter criterion is to emphasize that the language choice of published papers is solely dependent on the intention of the authors, not a monolingual publication policy of the journals. Finally, the collected articles were classified into two major domains, science and non-science, and then divided into 3 different sub-disciplines from which 3 journal titles were collected. The journal titles are listed in Table 2. Specifically, the articles in science fields included those in: 1) medical science, 2) technology and engineering, and 3) veterinary science and biology. The articles in non-science fields included those relevant to: 1) business and economics, 2) social and political science, and lastly 3) education as summarized in Figure 1 below.

In order to examine the rise of English as an academic lingua franca, we compared articles published in journals issued in two different years, specifically in 2005 and in 2015. The number of journals published in these two years was compared to entail a pattern of language choice change over time in Thai academia. We chose these two particular years as representative since we believe that the 10-year interval would be enough to project the trends of language choice among scholars. We included one journal from the education field that was issued in 2007, instead of in 2005, due to the lack of availability of earlier issues. We have hypothesized that even though the Thai articles are 
TABLE 2 The Selected Journal Titles

\begin{tabular}{|c|c|c|c|c|c|}
\hline \multirow[t]{2}{*}{ Field } & \multirow[t]{2}{*}{ Subfield } & \multirow[t]{2}{*}{ Thai Title } & \multirow[t]{2}{*}{ English Title } & \multicolumn{2}{|c|}{ Number of articles } \\
\hline & & & & Year 2005 & Year 2015 \\
\hline \multirow[t]{11}{*}{ Science } & Biology and & วารสารสัตว์ปาเมืองไทย & Journal of Wildlife in Thailand & 16 & 16 \\
\hline & $\begin{array}{l}\text { Veterinary } \\
\text { science }\end{array}$ & $\begin{array}{l}\text { วารสารสัตวแพทยศาสตร์ } \\
\text { มหาวิทยาลัยขอนแก่น }\end{array}$ & KKU Veterinary Journal & 23 & 14 \\
\hline & & วารสารสัตวแพทย์ & Journal of Kasetsart & 18 & 10 \\
\hline & & & Veterinarians & & \\
\hline & $\begin{array}{l}\text { Medical } \\
\text { science }\end{array}$ & $\begin{array}{l}\text { วารสารการแพทย์และ } \\
\text { วิทยาศาสตร์สุขภาพ }\end{array}$ & $\begin{array}{l}\text { Journal of Medical Science and } \\
\text { Health Sciences }\end{array}$ & 28 & 17 \\
\hline & & วารสารสวนปรุง & Bulletin of Suanprung & 14 & 13 \\
\hline & & วารสารเภสัชศาสตร์อีสาน & $\begin{array}{l}\text { Isan Journal of Pharmaceutical } \\
\text { Sciences }\end{array}$ & 13 & 24 \\
\hline & $\begin{array}{l}\text { Technology } \\
\text { and } \\
\text { Engineering }\end{array}$ & $\begin{array}{l}\text { วารสารมหาวิทยาลัย } \\
\text { นเรศวร: วิทยาศาสตร์และ } \\
\text { เทคโนโลยี, }\end{array}$ & $\begin{array}{l}\text { Naresuan University Journal: } \\
\text { Science and Technology (NUJST) }\end{array}$ & 20 & 34 \\
\hline & & $\begin{array}{l}\text { วารสารก้าวทันโลก } \\
\text { วิทยาศาสตร์ }\end{array}$ & Advanced Science & 13 & 22 \\
\hline & & วิศวกรรมสาร มก. & Kasetsart Engineering Journal & 24 & 27 \\
\hline & & Total & & 169 & 177 \\
\hline \multirow[t]{10}{*}{$\begin{array}{l}\text { Non- } \\
\text { science }\end{array}$} & $\begin{array}{l}\text { Business and } \\
\text { Economics }\end{array}$ & $\begin{array}{l}\text { วารสารจุพาลงกรณ์ธุรกิจ } \\
\text { ปริทัศน์ }\end{array}$ & Chulalongkorn Business Review & 24 & 22 \\
\hline & & วารสารพัฒนบริหารศาสตร์ & NIDA Development Journal & 8 & 27 \\
\hline & & วารสารบริหารธุรกิจ & Thammasat Business Journal & 16 & 16 \\
\hline & Social and & ดำรงวิชาการ & Damrong Journal & 23 & 16 \\
\hline & Political & วารสารลุ่มน้าโขง & The Journal of Mekong Societies & 16 & 16 \\
\hline & science & วารสารสังคมศาสตร์ & The Journal of Social Sciences & 12 & 16 \\
\hline & Education & $\begin{array}{l}\text { วารสารวัดผลการศึกษา } \\
\text { มหาวิทยาลัยมหาสารคาม }\end{array}$ & $\begin{array}{l}\text { Journal of Educational } \\
\text { Measurement, Mahasarakam } \\
\text { University }\end{array}$ & 10 & 27 \\
\hline & & วารสารวิชาการศึกษาศาสตร์ & Journal of Education & 16 & 26 \\
\hline & & $\begin{array}{l}\text { วารสารศึกษาศาสตร์ } \\
\text { มหาวิทยาลัยมหาสารคาม }\end{array}$ & Journal of Education MsU & 9 & 17 \\
\hline & & Total & & 134 & 183 \\
\hline
\end{tabular}




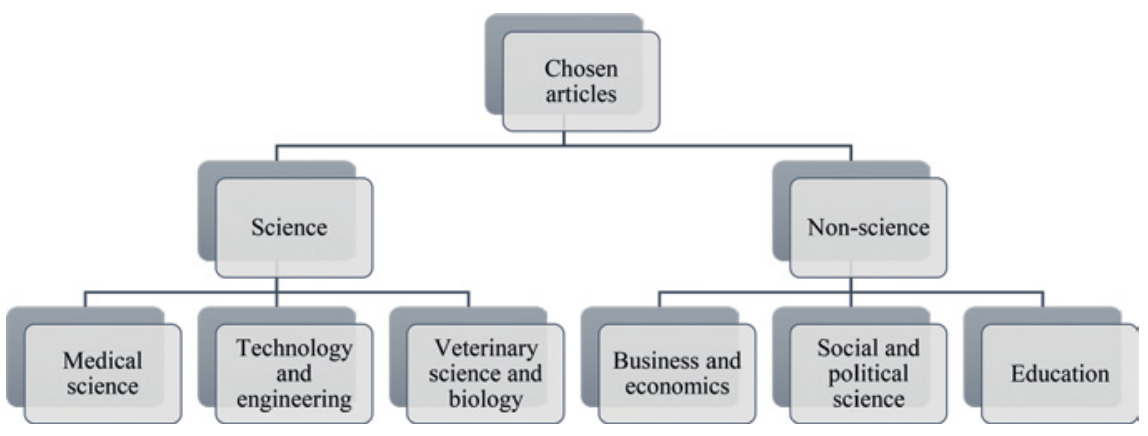

FIGURE 1 The subfields of collected articles

the mainstream, the number of English articles in Thai academic journals increased in 2015 especially those in science journals, with the expectation that the result, would reflect the rising trend of using English by Thai academics.

The second part will describe the reasons for choosing language as a medium of national academic exchange. We collected data by distributing online questionnaires to scholars from both science and non-science fields. The questionnaires were filled out by 73 respondents $(\mathrm{N}=73$ : Male 40; Female 32; Unidentified 1). Their ages ranged from 23 to 62 years old. The questionnaires consisted of 3 parts: 1) personal information and background (i.e., gender, age, educational background, a study field, working experience);2) their academic experience (i.e., number of academic papers published in English, Thai, or both); and 3) the language preference regarding reading and writing academic manuscripts (i.e., opinions towards reading and drafting academic papers in English, Thai, or both). The results from both parts will be reported in the following sections.

\section{$4 \quad$ Language Choice of Thai Academic Publications}

This section presents the quantitative analysis of the languages chosen for publication and how language use patterns have changed over time.

\subsection{Language Choice in Academic Publications in General}

Unlike previous studies, the data analysis reveals the dominant role of Thai as a language of national academic publications in both years. As summarized in Figure 2, despite the fact that there is an exponentially higher number of articles written in Thai in Thai academic journals, there has been a noticeable increase in articles written in English over this timescale. This situation might 


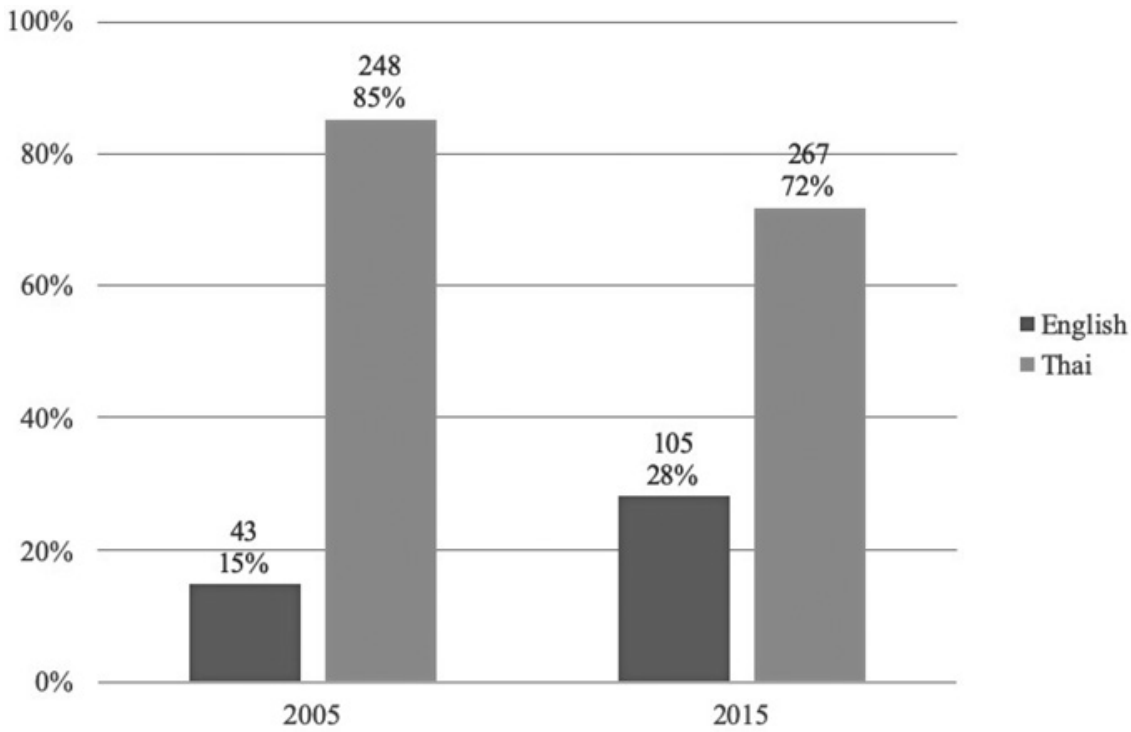

FIGURE 2 The articles published in 2005 and 2015 based on the written language

imply the increasing interference of English as an academic lingua franca among Thai academics. This trend is not idiosyncratic only in Thailand but is indeed universal in many academic communities as further mentioned in the discussion. In the next part, we will describe the data analysis based on the disciplines of the articles.

\subsection{Disciplinary Language Choice of Academic Publications}

Disciplinary distinctions between science and non-science articles are presented in Figure 3, which compares the number of articles written in different languages. According to Figure 3, the number of articles written in Thai still exceeds what is written in English in both disciplines. However, the number of English science articles increased from nearly $20 \%$ in 2005 to $40 \%$ in 2015 while those in non-science disciplines experienced only a slight increase (only $4 \%)$.

\subsubsection{The Dominant Role of English in Medical Science Journals}

When focusing particularly on science journals, we found an interesting pattern of language choice as summarized in Figure 4. Overall, in biology and veterinary science and science and technology, more Thai language articles were found ( $78 \%$ and $83 \%$ respectively) compared to English $(22 \%$ and $17 \%)$. Surprisingly, English was more preferable in medical science articles (53\%). 


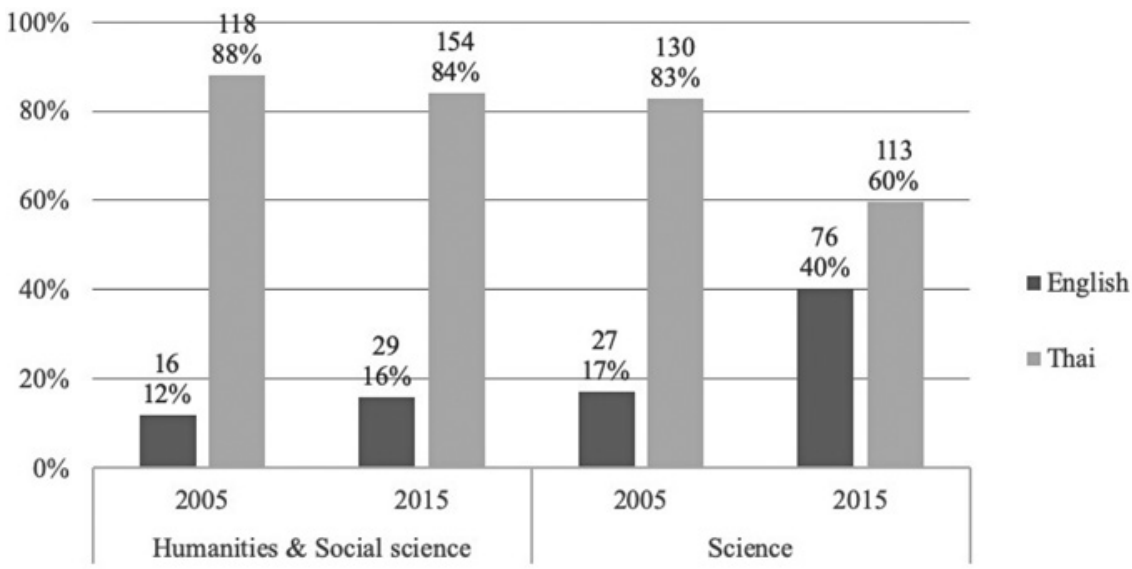

FIGURE 3 The number of articles written in Thai or English in 2005 and in 2015

$100 \%$

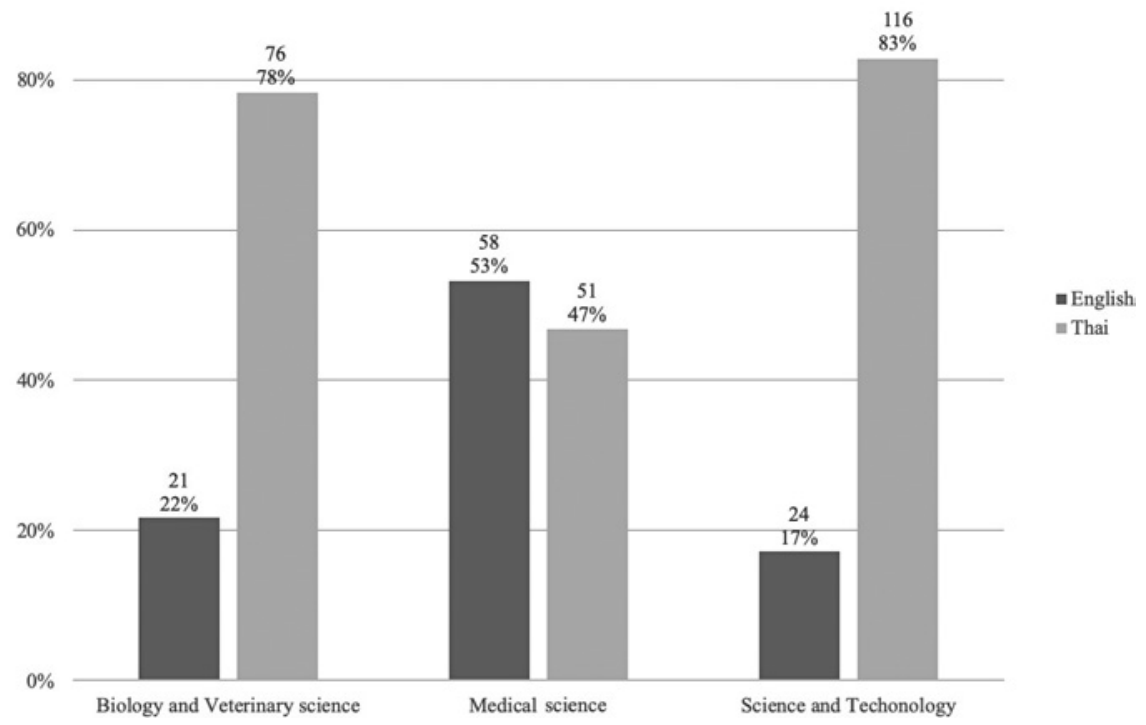

FIGURE 4 The overall percentage of science articles based on disciplines

If we take a closer look about time differences, we can clearly find an increasing pattern of English articles in these three disciplines, especially medical science as illustrated in Figure 5. In 2005, as expected, Thai played a more prominent role in writing science articles in every discipline as reflected in the vast majority of articles. In 2015, the number of Thai articles relevant to biology and 


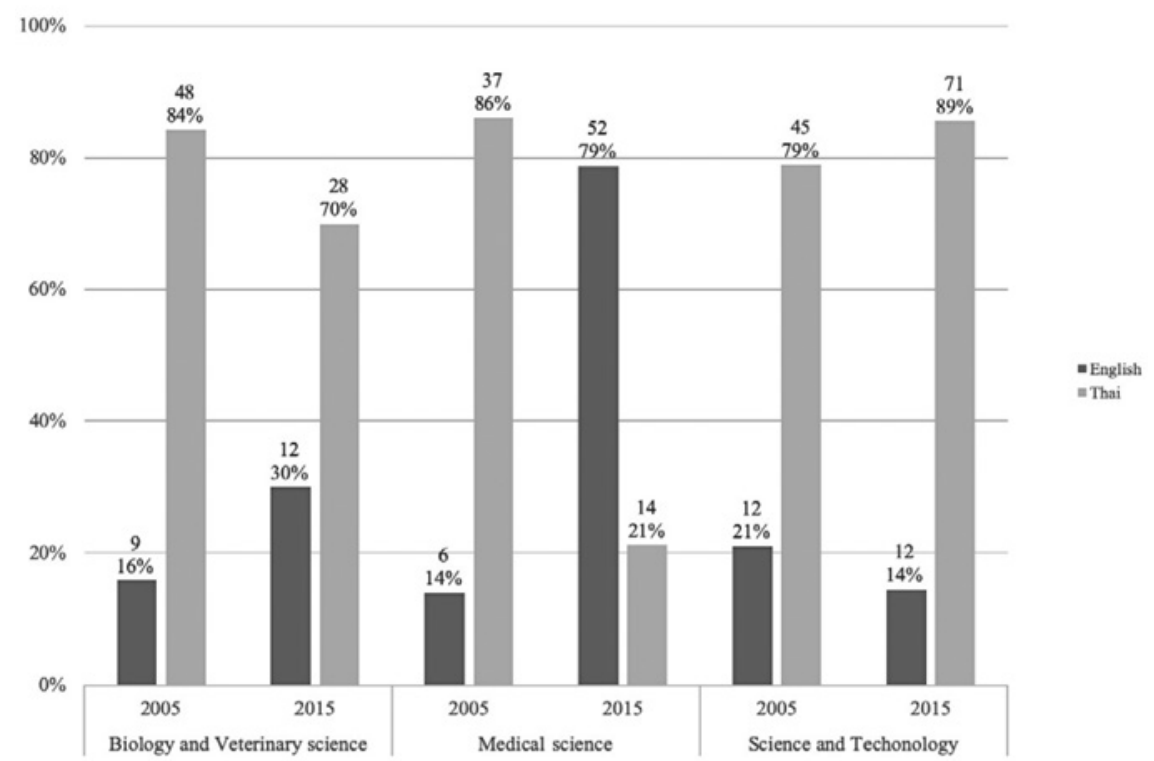

FIGURE 5 The comparison between Thai and English science articles based on the disciplines in 2005 and in 2015

veterinary science and science and technology still exceeded those written in English; nevertheless, the former experienced a twofold increase from $15 \%$ in 2005 to $30 \%$ in 2015 while the latter experienced the opposite trend. Conversely, a substantial increase in the number of English articles in medical science journals rose to $79 \%$. To sum up, even though Thai is still the dominant language of Thai national science journals, the data analysis reveals the compelling growth of English particularly in the field of medical science.

\subsubsection{Thai as the Dominant Language in Non-science Journals}

Compared to science journals, the non-science disciplines, including business and economics, social and political science, and education, illustrate the dominant role of Thai as a medium of academic exchange. Figure 6 compares the number of articles written in Thai and English and indicates that Thai is the dominant language chosen in writing articles whereas English is not popular due to a small number of articles. Among the three disciplines, English articles were found to be the most popular in business and economics (approximately $25 \%$ ) whereas in education only a mere $2 \%$ can be found.

Similar to science articles, when considering the time difference, we can still find the predominant pattern of Thai in 2005 and 2015 in non-science journals. Figure 7 explains the variation according to the period of article publications. 


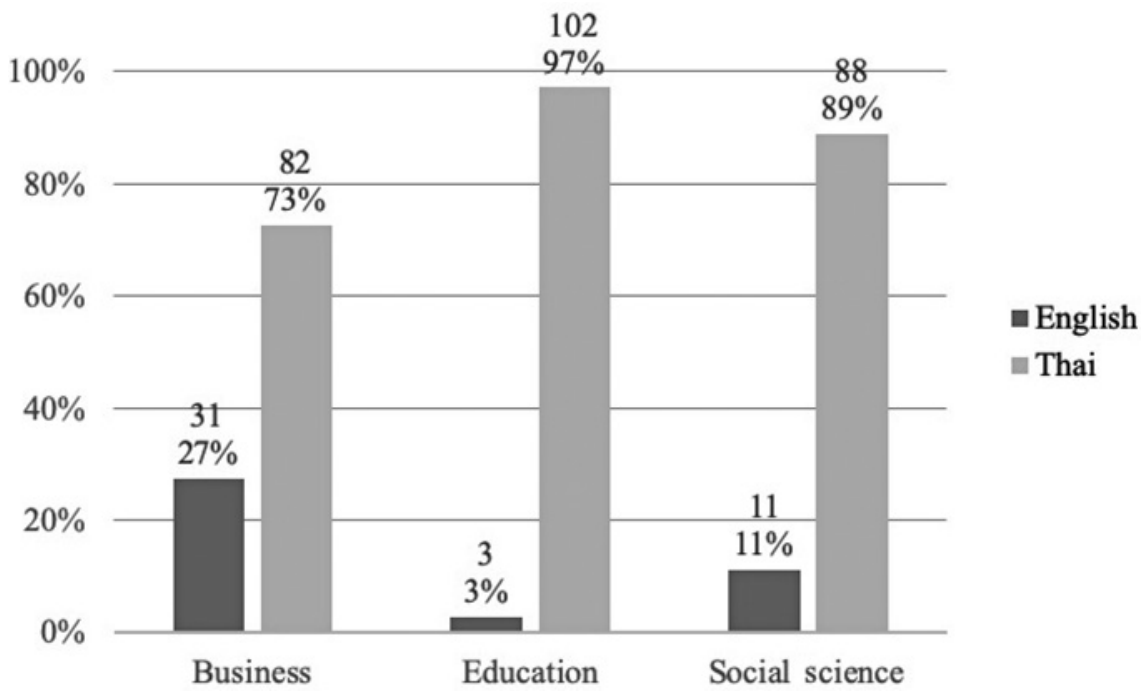

FIGURE 6 The overall non-science articles based on disciplines

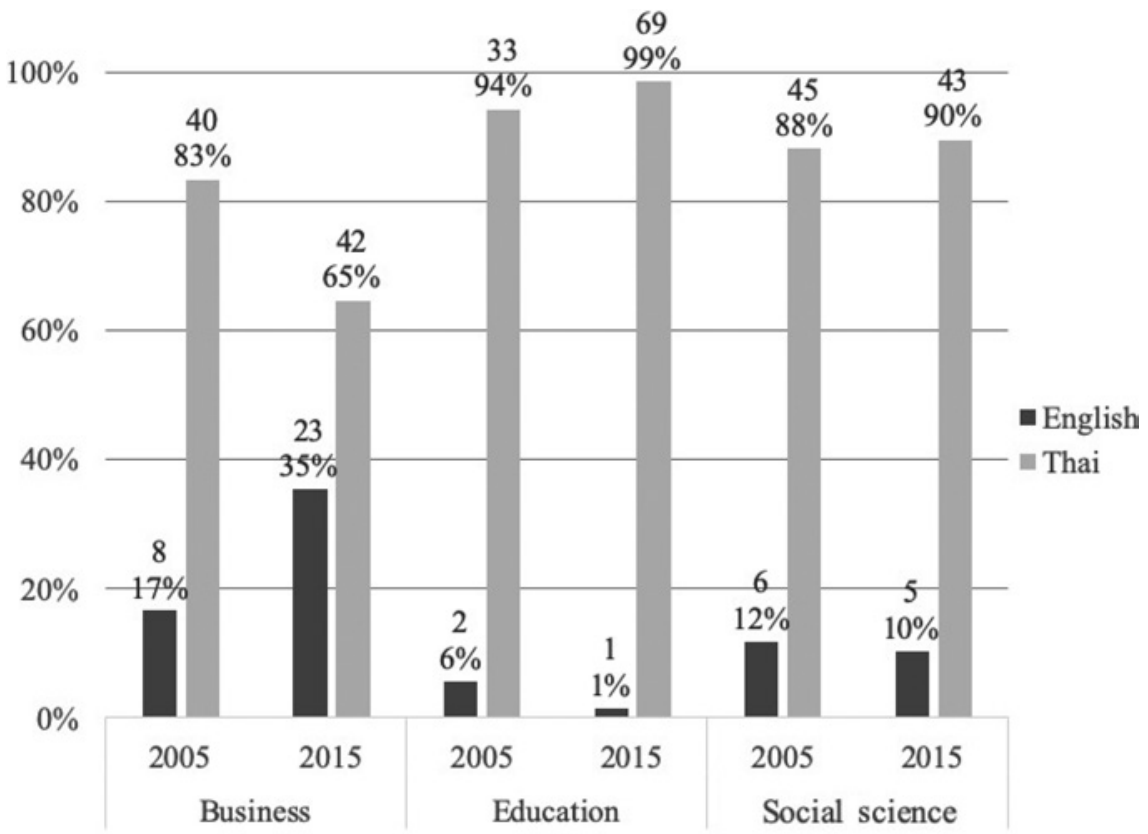

FIGURE 7 The comparison between Thai and English non-science articles based on the disciplines in 2005 and in 2015 
The comparison shows that English articles in business and economics increased by $20 \%$. Those in social and political science remain the same through the decade whereas those in education dropped slightly. To summarize, the role of Thai remained dominant in writing articles among non-science researchers in both periods. In the next part, we will report on the reasons of choosing languages of academic publications from our respondents.

\section{5}

The Reasons for Language Choice in Academic Articles

This part of the study reports the reasons for language choice in academic articles among Thai scholars from both non-science and science fields. As described in section 3, the three-part questionnaires were used to collect data from 73 respondents. The objectives of the questionnaire were to investigate the reasons why Thai academics in both fields choose to read and draft academic papers in English, Thai, or both. The findings were divided into two categories: 1) the reasons for reading papers in different languages; and 2) the reasons for drafting papers in different languages.

\subsection{Reasons for Reading Academic Papers in English, Thai, or Both 5.1.1 Non-science Respondents}

The reasons that Thai academics in non-science fields preferred to read papers in English could be grouped into eight themes. Those reasons include: 1) availability of the articles, 2) being up to date, 3) credibility of the articles, 4) content relatedness, 5) convenience in drafting, 6) familiarity with English reading, 7) authors' English language proficiency, and 8) terminology used in the field. Two non-science respondents stated that most of the papers in their field were written in English. Therefore, they thought that it was more convenient to read in English. Two other respondents stated that in their fields there was a lack of information written in Thai. Others mentioned that some topics were written in an international journal and have never been written by Thai authors. Another said that the information from English articles is more upto-date. One of the respondents explained that her work was about the English language. Thus, it was written in English. Another reason is that when it came to academic paraphrasing, it was easier for them to paraphrase the original text, which was written in English into English. Four respondents contended that for them English articles seemed to be more credible. One respondent simply said that she was familiar with articles written in English. One respondent chose to read an English article because they wanted to improve their English reading skills. One pointed out that most of the terminology in their 
field was written in English, while others said that they are familiar with English terminology in their fields.

The findings were slightly different with regards to Thai. The only reason why some Thai academics preferred reading information in Thai articles was related to their English proficiency. Four respondents expressed that they preferred Thai because they understand Thai better. One said that he could read faster if articles were written in Thai.

For non-science respondents, who read both Thai and English articles, there are seven reasons to support them. These include: 1 ) the availability of the sources, 2) the completeness of the information from various sources (i.e. Thai and English sources), 3) the objective(s) of their studies, 4) to get different perspectives, 5) the topics that they are working on, 6) the requirement of the journals, and 7) the context in which the study took place (i.e., in Thailand). One respondent pointed out that he worked on language, literature and culture whose information was available in both English and Thai. One stated that some information was available only in English or Thai and that was why she needed to use both English and Thai sources. One respondent said that she needed the information from both national and international sources. Similarly, one respondent stated that he could get more information if he was open to both languages. One respondent said that it depended on the objective of the reading. Two respondents shared that they would like to get the information from both English and Thai perspectives. Two others stated that sometimes two different languages could possibly provide different explanations for them to analyze and study. Two respondents needed to read both English and Thai resources because the article with which they had planned to publish their work required both languages. One pointed out that the theory that she based her study on was in English, but the context that she based her study on was in Thai. One said that he read both because he focused on the topics rather than the language itself. There were four respondents who indicated that it depends on the context in which they conducted their studies whether it required English or Thai.

\subsubsection{Science Respondents}

The reasons that Thai academics in science fields, chose to read their papers in English could be grouped into seven issues. These issues include: 1) the availability of the articles, 2) authenticity of the sources, 3) authors' English proficiency, 4) being up to date, 5) credibility towards the articles, 6) terminology used in the field, and lastly 7) the status of English as an international language. One respondent stated that he considered English as a conventional language used to draft academic papers in his field. Five respondents mentioned that 
most of the sources in their fields were written in English. One respondent believed that English sources were more various and up to date. Some respondents thought that English sources provided more profound knowledge and information, while three others simply stated that English sources were more credible. One respondent claimed that the content of English sources were more interesting, while another respondent said that most of the terminology in the field was in English. And one of the respondents wanted to learn more about the English terminology in the field. Four respondents contended that it was easier to understand when they read academic papers written in English. Two respondents chose to read English articles because they considered English as an international language.

For science academics who read papers in Thai, there were two reasons to support their decision: 1) their reading pace and 2) authors' English proficiency. Two participants noted that they understood the contents clearly when reading in Thai. One of them stated that the reason he chose to read Thai papers was that he did not understand the English terminology. One pointed out that they could read the papers faster when it was written in Thai.

For science respondents, who read both Thai and English papers, there are five themes that emerged including: 1) availability of the sources, 2) comparing and gaining information from both perspectives (i.e., English and Thai), 3) gaining various sources of information from both languages, 4) the relatedness of the articles, and 5) the topics of interest. One respondent said that it depended on the topic of interest if it was available in English or Thai. Another respondent mentioned that she read both English and Thai papers for comparing the information from both languages, since English and Thai articles may provide different pieces of information, and for adding up information that the other language might lack. Similarly, to non-science fields, one of the respondents stated that he focused on the contents of the articles rather than the language used. Another respondent said that when reading articles, he paid attention to the topics of interest rather than the language used. Last but not least, one respondent contended that it depended on the journal that provided relevant and useful information. So, it could be either English or Thai.

\subsection{Reasons for Drafting Academic Papers in English, Thai, or Both 5.2.1 Non-science Respondents}

The reasons for Thai academics in non-science fields to choose to draft academic papers in English could be grouped into seven issues: 1) accessibility of the articles to the target readers, 2) credibility of the articles, 3) authors' English language proficiency, 4) the language of the sources, 5) the status of English as an international language, 6) the requirement of the journals, and 7) 
terminology used in the field. One of the respondents wanted to present his work to more groups of readers such as both Thai and international readers. One respondent thought that it was more interesting to read if the article was written in English. One respondent informed us that she received her bachelor's and master's degree from international programs, so she was used to writing papers in English. Three respondents simply stated that they were familiar with English writing, while one of them stated that they were familiar with English terminology. Another one said that some terminology cannot be explained clearly in Thai. Two others said that there was no such terminology in Thai. One of the respondents stated that when it comes to explaining things straightforwardly, English could do a better job compared to Thai. Another one contended that she would like to maintain a sense of internationalization, thus she preferred using English to draft her work. One respondent mentioned that the reference sources were already in English; therefore, it would be easier to write in English. Two respondents explained that the programs that they are taking are English programs, so the papers must be done in English as required by their programs.

The reasons non-science academics chose to draft their academic papers in Thai could be grouped into four reasons, such as: 1) author's language proficiency, 2) publication reasons, 3) target reader reasons, and 4) the topic of the articles. Six respondents contended that it was easier for them to draft their papers in their mother tongue, and by doing so, they did not have to find a proofreader to proofread their papers and thereby reducing the process of publication. One respondent said that it was faster for him to write in his mother tongue. Four of the respondents said that they drafted their papers in Thai in order to explain things accurately. Two of the respondents simply said that they were more familiar with writing a paper in Thai. One contended that the publication process would be cheaper if the paper was written in Thai and there were more publishers for Thai-written papers. One respondent thought that a paper written in Thai would be accepted faster, while another mentioned that there are more Thai journals in the field, so that his paper would be accepted faster. One of them said that it was the requirement of the journal with which she sought to publish her paper. Two respondents assumed that most of the target readers were supposed to read Thai, while two others supported the idea that the titles of the journals were in Thai. One explained that he drafted the papers in Thai so that the readers would be able to read the article easier. Similarly, another respondent said that she had the intention to write for a Thai audience. Last but not least, one respondent said that he drafted the papers in Thai because the topics written were in the context of Thai culture. 
There were three reasons why non-science academics drafted their papers in both English and Thai. Those reasons are: 1) accessibility of the articles, 2) providing broader contexts and perspectives, and 3) publication reasons. One respondent said that she drafted her papers in both English and Thai in order to access both Thai and international readers. Another stated that she wanted to present different contexts and wider perspectives, while two others said that it depends on the requirement of the journals.

\subsubsection{Science Respondents}

For science academics, there are nine reasons to support why they drafted their papers in English. These are: 1) accessibility to articles, 2) authors' proficiency, 3) conventional language of the field, 4) credibility, 5) publication reasons, 6) program requirement, 7) academic award requirement, 8) terminology, and 9) target reader reasons. Three respondents stated that they drafted their papers in English so that their papers could be accessed easier by more readers, while three others said that it was easy to explain things in English. One said that it was easier for him to draft a paper in English. Another respondent stated that English is a conventional language for his field. And one of them contended that papers written in English seemed to be more credible. One respondent said that it was the requirement of the program that required the respondent to write in English because it was an international program, while another said that it was the requirement of the scholarship he received. One respondent pointed out that he wanted to get published in an international journal. Similarly, another said that the target journal that he aimed to get his work published in was an international journal. And the last reason was that most of the terminology in the fields of the respondents were in English.

There are four reasons while Thai science academics drafted their papers in Thai. Those are: 1) authors' proficiency, 2) publication reasons, 3) the requirement of the journals, and 4) target reader reasons. Four respondents contended that it is easier for them to write in Thai. One of them mentioned specifically about the ability to outline ideas in Thai. One of the respondents said that he could use the Thai language better. Two of the respondents stated that they only aimed to present their work at the national level. And one mentioned that it was easier to get published if the author wrote in Thai. One said that it was the requirement of the article to draft the paper in Thai. Another respondent said that he wanted his paper to access all levels of audiences. Similarly, another respondent contended his intention to write for Thai readers. Another one thought that it would be faster for readers to read in Thai. And another one thought that it would be easy for readers to read in Thai. 
In conclusion, the reasons why Thai academics in non-science and science read and drafted their papers in English, in Thai, or in both Thai and English are similar. More specifically, the most common reasons why both fields read papers in English are the availability and the credibility of the sources, while the most common reasons why both fields drafted their papers in English are authors' language proficiency and the terminology used in their field.

\section{Discussion and Conclusion}

This current study sheds light on the language choice of Thai scholars from science and non-science disciplines who published academic articles in Thai national journals and also discusses the reasons of choosing such languages. Given that our findings are based on a limited number of collected articles, the interpretation should be treated with considerable caution. However, the data analysis reveals the dominant role of Thai in two years, 2005 and in 2015, as reflected by the number of predominantly published articles. Even though Thai plays a major role in academic exchange among Thai scholars, the growth of English is still noticeable. The number of English articles written by Thai's increased between those two years. This fact may imply the increasing importance of English in the Thai academic domain as an academic lingua franca, especially among medical science scholars and researchers. Perhaps the most significant finding we have found is the growth of English as an academic lingua franca in Thai national journals, specifically in the field of medicine.

From the respondents to the online questionnaire, the detailed reasons in the previous section could be categorized into four main different reasons in choosing languages of their articles. Those are author-oriented, resourceoriented, reader-oriented, and other requirements. Some respondents who prefer Thai as a medium in writing journals suggested different reasons. The most common reason is the authors' language proficiency. To illustrate, most of the respondents were familiar with writing in their mother tongue in this case Thai. In addition, one interesting factor is the reader-oriented. They target the expected readers of the journals who are assumed to be Thai. As a result, they accommodate their language in writing articles to suit the audience as some responses in the questionnaire state that, the readers can read and understand the content better and faster in Thai and It is easy for the readers to understand the article.

In contrast, respondents who prefer English as a medium in writing journals indicated different reasons. The most common reason is author's language 
familiarity. For instance, three respondents stated that they were familiar with writing papers in English. These findings correspond with Pupipat (1998) in that most Thai scientists were familiar with writing scientific English papers. Other reasons are that the respondents believed that English enhances papers' interest and creditability among targeted readers. They also believed that English could be used to explain contents clearer. Moreover, the main use of English is due to its availability of technical terms in their fields of study and their English proficiency. Apart from the inadequate terminology, another interesting reason is the requirement of the study programs in which the respondents studied or are studying. All study programs in Thailand have a top-down policy that require students to publish articles in academic journals, so those who have attended or are attending an English-based program are required to publish their work in English even in Thai-language journals. One of the reasons that English-based programs require their students to publish their work in English may be because they want to promote the internationality of their program, as explained in Phothongsunan (2016). He claimed that many Thai researchers acknowledge the role of English in academic publications in order to increase the internationality of Thai academic journals, as supported by his findings, "writing scholarly articles for publication in English become increasingly necessary" (p. 684). This perspective towards English might encourage the growth of English in scholarly publications by Thai academics which follow the universal trend of English as a world academic lingua franca as found in other academic communities (such as Xian 2006; Yu et al. 2018; Hamel 2007; Sano 2002).

To conclude, despite the limitations of chosen years in this study, the analysis reveals the growing use of English in Thai scholarly publications, especially among those in medical science. What should be done further is an in-depth analysis of researchers' background whether it is a factor of language choice in the academic domain or not. In addition, the comparison of language choice in the academic exchange in non-English native regions such as in ASEAN countries should be encouraged to shed the light on the growth of English in ASEAN academic communities.

\section{Acknowledgements}

Finally, as the first author participates in the research project: The competing roles of the national languages and English in ASEAN countries: Study of language choice in the domains of law, media, education, literature, and politics, 
we would like to express our gratitude to Prof. Dr. Amara Prasithrathsint, the project leader, who encouraged us to conduct this study. We also would like to thank the reviewers who gave us constructive comments to improve the previous drafts of this paper. Last but not least, we also would like to thank Thailand Research Fund for the financial support on this project.

\section{References}

Biyaem, S. 1997. Learner Training: Changing Roles for a Changing World, Educational Innovation for Sustainable Development. 3rdUNESCO-ACEID International Conference: Bangkok.

Canagarajah, A. S. 2002. A Geopolitics of Academic Writing. Pittsburgh: University of Pittsburgh Press.

Curry, M. and T. Lillis. 2004. Multilingual Scholars and the Imperative to Publish in English: Negotiating Interests, Demands and Rewards. TEOSOL Quarterly 38: 663-688.

Crystal, D. 1997. English as a Global Language. Cambridge: Cambridge University Press.

Crystal, D. 2003. English as a Global Language (2 ${ }^{\text {nd }}$ ed.). Cambridge: Cambridge University Press.

Foley, J. A. 2005. English in ... Thailand. RELC Journal 36: 223-34.

Glass, T. 2009. Why Thais Write to other Thais in English. World Englishes 28.4: 532-543. Graddol, D. 2006. English Next. Why Global English May Mean the End of 'English As A Foreign Language. London: The British Council.

Gotti, M. 2017. English as a Lingua Franca in the Academic World: Trends and Dilemmas. Lingue Linguaggi 24: 47-72.

Hamel, R. E. 2007. The Dominance of English in the International Scientific Periodical Literature and the Future of Language Use in Science. AILA Review 20: 53-71.

Henshall, A. C. 2012. English as an International Language and Language Policies in Economics Journals. Anglo Saxonica III, III (4), 131e164. http://hdl.handle.net/10451/ 7974.

Henshall, A. C. 2018. English Language Policies in Scientific Journals: Signs of Change in the Field of Economics. Journal of English for Academic Purposes 36: 26-36.

Kirtikara, K. 2005. One Century of Modernization and Four Decades of Industrialization of Thailand: Mental and Social Exclusion by Education and the Rise and Fall of Languages. ThaiT Esol Focus, May: 2-13.

Lillis, T., A. Hewing, D. Vladimirou and M. J. Curry. 2010. The Geolinguistics of English as an Academic Lingua Franca: Citation Practices Across English-Medium National and English-Medium International Journals. International Journal of Applied Linguistics 20.1: 111-135. 
Phothongsunan, S. 2016. Thai University Academics' Challenges of Writing for Publication in English. Theory Pract. Lang. Stud 6.4: 681-685. http://dx.doi.org/10.17507/ tpls.0604.04

Pupipat, A. 1998. Scientific Writing and Publishing in English in Thailand: The Perceptions of Thai Scientists and Editors. New York: Columbia University.

Ren, S. and R. Rousseau. 2004. The Role of China's English-Language Scientific Journals in Scientific Communication. Learned Publishing 17: 99-104. doi:10.1087/095315104 322958472 .

Sano, H. 2002. The World's Lingual Franca of Science. English Today 18.4: 45-49.

Tardy, C. 2004. The Role of English in Scientific Communication: Lingua Franca or Tyrannosaurus Rex?. Journal of English for Academic Purposes 3: 247-69.

Van Dijk, T. 1994. Academic Nationalism. Discourse and Society 5: 275-276.

Wiriyachitra, A. 2002. English Language Teaching and Learning in Thailand in this Decade. Thai TESOL focus 15.1: 4-9.

Wongsothorn, A. 2000. Thailand. In Ho Wah Kam and Ruth Y. L. Wong (Eds.), Language Policies and Language Educations: The Impact on East Asian Countries in the Next Decade (pp. 307-20). Singapore: Times Academic Press.

Xian, J. 2006. English-Language Academic Journals from China: A Great Opportunity. Learned Publishing 19: 9-13.

$\mathrm{Yu}, \mathrm{H} ., \mathrm{S}$. Xu and T. Xiao. 2018. Is there Lingual Franca in Informal Scientific Communication? Evidence from Language Distribution of Scientific Tweets. Journal of Informetrics 12: 605-617. 